JURNAL AL BAYAN: JURNAL JURUSAN PENDIDIKAN BAHASA ARAB

p-ISSN 2086-9282 | e-ISSN 2549-1229

http://ejournal.radenintan.ac.id/index.php/albayan/index

\title{
Integration of Local Wisdom in Arabic Learning
}

\author{
Noza Aflisia ${ }^{1 *}$, Rini $^{2}$, Ahmad Fikri $^{3}$ \\ ${ }^{1}$ Arabic Education Study Program Institut Agama Islam Negeri Curup, Indonesia \\ ${ }^{2}$ Arabic Education Study Program Institut Agama Islam Negeri Curup, Indonesia \\ ${ }^{3}$ Arabic Education Study Program Institut Agama Islam Negeri Kerinci, Indonesia
}

Article History:

Received : August 15, 2019

Revised : September 25, 2019

Accepted : October 20, 2019

Published : December 01, 2019

$\overline{\text { Keywords: }}$

Mastery; Nationalism; Natural

Surroundings; Subject Matter

*Correspondence Address:

nozaaflisia@iaincurup.ac.id

\begin{abstract}
To realize Arabic learning based on local wisdom, the vocabulary contained in the material should be directed to vocabulary related to local wisdom or the characteristics and potential of the region in the local area. This research aims to explain the forms of integration the local wisdom of Kerinci area in Arabic learning, both in listening, speaking, reading, and writing skills. So far, Arabic learning materials still expose vocabulary found only in Middle East Countries. For them who never seen and heard for the first time the vocabulary certainly feels strange, so it requires more treatment in giving understanding to students. This research is a library research through the stages of collecting data, identifying, understanding, analyzing, and determining. The results of this research indicate that to integrating the local wisdom of Kerinci region in Arabic learning can be done by modifying the content of the subject matter, which includes the forms of local wisdom possessed by Kerinci region in listening, speaking, reading, and writing. This is done so that the knowledge gained by students is not only in the mastery of Arabic vocabulary and grammar, but also in the knowledge of the natural surroundings such as, Kerinci Folk Songs, Kerinci Folk Stories, Kerinci Tourism, and so forth. So that sense of belonging and nationalism can be formed in the young generation who are Arabic learning.
\end{abstract}

\section{Introduction}

Local wisdom is something that is very close to the community. Local wisdom is present explicitly through a long process from one generation to the next and evolves with the community and its environment. Local wisdom is scholarship of the wealth owned by the local area in the form of knowledge, beliefs, norms, customs, culture, insight and so on which is a legacy and must be preserved as identity and guidance in guiding people to act appropriately in life. ${ }^{1}$ In accordance with what was expressed by

${ }^{1}$ Unga Utari, I. Nyoman Sudana Degeng, dan Sadun Akbar, "Pembelajaran Tematik Berbasis Kearifan Lokal Di Sekolah Dasar Dalam Menghadapi Masyarakat Ekonomi Asean (MEA)," Jurnal Teori 
Sumarmi \& Amiruddin, local wisdom is knowledge of local conditions used by local communities to survive in their environment in the form of systems of belief, norms, and culture that are expressed in traditions and myths that are held in a time that is not briefly by the community. ${ }^{2}$ Local wisdom can be in the form of culture, customs, folklore, folk songs, language, natural resources and other wise things that have lived and been integrated into people's lives. So, they have become the characteristic of the area.

Preserving local wisdom can be done with a variety of strategies including integrating local wisdom in education and teaching as early as possible to the younger generation to love the existing local wisdom. But, nowadays, it is not uncommon for local wisdom to be eroded by technological developments. Humans know about many things that are far from it, only through the internet connection as a form of technological development. Humans know the culture of other countries, but forget to learn the culture and local wisdom that is owned by the surrounding area. Humans reach the pinnacle of technological progress, but not the knowledge of local wisdom they possess, whereas ideally, socialization and knowledge of local wisdom continue to be developed and ascended along with technological developments and world progress.

The research conducted by the previous researchers has explained how the presence of local wisdom in lesson content can improve learning effectiveness. In art and culture learning, it is taught by inculcating cultural values that are in accordance with the environment, namely honesty, discipline, responsibility and sensitivity to the environment. ${ }^{3}$ In Ponorogo, East Java, it is known as the culture of Samin which teaches the values of wisdom that are relevant to the values in Islamic teaching ${ }^{4}$, whereas in Yogyakarta it is called Kawruh Pamomong which is full of love in educating children ${ }^{5}$. By integrating these values into the content of the lessons, it is expected that these attitudes will become values that are reflected in attitudes and behavior in daily life. So,

\footnotetext{
Dan Praksis Pembelajaran IPS $\quad$, $\quad$ no. $1 \quad$ (30 April 2016$):$ 39-44, https://doi.org/10.17977/jtp2ips.v1i1.5861.

2 Sumarmi dan Amiruddin, Pengelolaan Lingkungan Berbasis Kearifan Lokal (Yogyakarta: Aditya Medai Publishing, 2014).

${ }^{3}$ Dedi Rosala, "Pembelajaran Seni Budaya Berbasis Kearifan Lokal dalam Upaya Membangun Pendidikan Karakter Siswa di Sekolah Dasar," Ritme 2 (Februari 2016).

${ }^{4}$ Renny Oktafia dan Imron Mawardi, "IslamIc Values In The TradITIon of SamIn CommunITy In EasT JaVa,” QIJIS (Qudus International Journal of Islamic Studies) 5, no. 1 (2017): 18.

${ }^{5}$ Dhiniaty Gularso, Sugito Sugito, dan Zamroni Zamroni, "Kawruh Pamomong: Children Education Based on Local Wisdom in Yogyakarta,” Jurnal Cakrawala Pendidikan 38, no. 2 (29 Juni 2019): 343-55, https://doi.org/10.21831/cp.v38i2.21556.
} 
the devotion for the environment increases and it also can overcome the presence of destructive nature and the presence of radicalism. ${ }^{6}$

Furthermore, learning process that has implemented local wisdom in learning content is physics through the teaching instrument named Active Learning Tournament. ${ }^{7}$ History lessons through the use of local sources where the student lives, Citizenship Education lessons through the cooperative learning model Problem Based Learning and Value Clarification, biodiversity through the application of the Konservasi Berbasis Kearifan Lokal (Local Wisdom-Based Conservation Program) (KBKL) ${ }^{8}$, the education of disasters through an explanation of the relationship between humans and the natural environment and the surrounding cultural environment ${ }^{9}$, science lessons through the reconstruction of these scientific concepts so as to foster the value of students' conservation character. ${ }^{10}$ In addition to the content of the wisdom-based content, students' awareness of local wisdom will also increase through the use of Project Based learning with a combination of CTL (Communicate Language Teaching). ${ }^{11}$

The entire research which is revealed seems collaborating local wisdom in various fields of study, whether arts and culture, physics, history, civic education, biodiversity, disaster education, and science. In these fields of study are more inclined to the learning model and culture. The links discussed in all the study areas mentioned are general subjects not in Islamic studies or language. The local wisdom is actually closely related to religion and language, because these two things grow and live together with the local wisdom of a region. In this paper the researcher associates fully local wisdom with language learning, specifically Arabic which is applied directly in the content of Arabic material itself.

${ }^{6}$ Azizah Maulina Erzad dan Suciati Suciati, "The Existence of Kudus Islamic Local Culture to Prevent Radicalism in Globalization Era," QIJIS (Qudus International Journal of Islamic Studies) 6, no. 1 (4 Juli 2018): 39, https://doi.org/10.21043/qijis.v1i1.3460.

${ }^{7}$ Wahyu Trias Wulandari dan Mundilarto Mundilarto, "Developing Physics Active Learning Kits for Local Wisdom-Based Learning Tournament," Cakrawala Pendidikan, no. 3 (2016): 13.

8 Suroso Mukti Leksono dan Nuryani Rustaman, "Pengaruh Penerapan Program Perkuliahan Biologi Konservasi Berbasis Kearifan Lokal Terhadap Kemampuan Literasi Biodiversitas Mahasiswa Calon Guru Biologi,” No. 1 (2015): 8.

9 Mirza Desfandi, "Urgensi Kurikulum Pendidikan Kebencanaan Berbasis Kearifan Lokal Di Indonesia," Sosio-Didaktika: Social Science Education Journal 1, No. 2 (28 Desember 2014): 191-198198, Https://Doi.Org/10.15408/Sd.V1i2.1261.

${ }^{10}$ Miranita Khusniati, "Model Pembelajaran Sains Berbasis Kearifan Lokal Dalam Menumbuhkan Karakter Konservasi," Indonesian Journal Of Conservation 3, No. 1 (1 Juni 2014), Https://Journal.Unnes.Ac.Id/Nju/Index.Php/Ijc/Article/View/3091. 
Through Arabic learning based on local wisdom, it is hoped that Arabic learners are not only experts in Arabic through mastering qawaid and muhadatsah, but also learning that is able to respect the surrounding nature, namely culture and be able to always preserve it according to its capacity. Currently the development of Arabic learning has been done by many teachers and researchers. Not only in terms of learning media but also those related to Arabic learning content. Alkazemi developed English to Arabic translation engine namely AccurIT which produced a translation that was quite accurate and better than Google so far. ${ }^{12}$ Previously, Computer Assisted Language Learning (C.A.L.L) ${ }^{13}$ and Teacher Assisting and Subject Adaptive Material (TASAM) 14 systems have been made part of the development in Arabic learning so that Arabic learning is not only as a language learning goal. But it can also be used as a tool to study other material, such as science, mathematics, nature ${ }^{15}$, and so on.

During this time Arabic learning materials related to istima, kalam, qiroah, and kitabah still describe vocabulary that only exists in Middle Eastern countries, such as camels, deserts, wheat and so on. For those who have never seen and heard this vocabulary for the first time, they certainly feel strange, so that it requires deeper treatment to give understanding to students. In providing this understanding, educators must associate the object with similar objects found in Indonesia, such as linking the word camel to chicken, desert to the island, and the same type of wheat with rice. Likewise in discussing activities and places carried out by foreign people, it would be more effective and efficient to explain the vocabulary about the daily activities of students and the places they often see and meet. Things like this are also expected to be found in local wisdom-based learning. To realize Arabic language learning based on local wisdom, the foreign vocabulary contained in the material should be directed to

11 Amporn Sa-ngiamwibool, "Raising Learner Awareness Of Local Wisdom In Tour-Related Project Teaching," Indonesian Journal of Applied Linguistics 1, no. 2 (5 Januari 2012): 1, https://doi.org/10.17509/ijal.v1i2.659.

12 Basem Alkazemi dkk., "AccurIT: a prototype of a machine translation engine for English to Arabic translation," International Journal of Innovation and Learning 26, no. 2 (1 Januari 2019): 115-30, https://doi.org/10.1504/IJIL.2019.101274.

${ }^{13}$ Nadia Selim, "Arabic teaching at Islamic Schools: A C.A.L.L for resource development.," (1 Februari 2016).

${ }^{14}$ Nahla Aljojo, Iqbal Alsaleh, dan Areej Alshamasi, "Difficulties in adapting feedback for individual learning styles in the Arabic Teacher Assisting and Subject Adaptive Material (TASAM) system," International Journal of Management in Education 10, no. 3 (1 Januari 2016): 293-308, https://doi.org/10.1504/IJMIE.2016.077510.

15 Tamer Amin dan Diala Badreddine, "Teaching science in Arabic: diglossia and discourse patterns in the elementary classroom," International Journal of Science Education 0, no. 0 (28 Juni 2019): 1-41, https://doi.org/10.1080/09500693.2019.1629039. 
vocabulary related to local wisdom or the characteristics and potential of the region (regional superiority) in the local area.

One area that has a lot of local wisdom to be preserved is the Kerinci area, a district located in Jambi Province. The Kerinci area is full of customs and culture to friendly natural conditions, so, it can produce to a lot of local wisdom. The researcher formulated the problem of this research, namely how to integrate local wisdom in Arabic learning. To answer the problem formulation, the researcher directed to several research questions, namely how is the integration of the local wisdom of the Kerinci area in learning istima, kalam, qiroah, and kitabah? This study aims to analyze the forms of integration of the local wisdom of the Kerinci area in Arabic learning, both in istima, kalam, qiroah, and kitabah skills. This research is important to study in order to produce effective and efficient Arabic learning.

\section{Theoretical Support}

\section{Kerinci Local Wisdom}

Because the Kerinci Regency region has beautiful nature and the indigenous people who stay, then this area has a lot of local wisdom, among which are grouped as follows:

\section{Culture}

The Kerinci region has many cultures passed down from one generation to other generations. The culture that unites the community to the harmony and unity is always maintained until now. Among these cultures are: Kenduri Sko which is a public party that involves many people and spends a lot of costs with activities in the form of inauguration of traditional titles, cleansing heritage objects, and art performances (Pencak Silat, Iyo-iyo Dance, Rangguk and so on). ${ }^{16}$ Sike Rebana is a musical activity by chanting sentences of praise to the ruler of the universe in the form of rhymes and poems using tambourines as musical instruments. ${ }^{17}$ Asik Niti Naik Mahligai dance is a traditional dance with a simple movement that is performed

16 Yolla Ramadani dan Astrid Qommaneeci, "Pengaruh Pelaksanaan Kenduri Sko (Pesta Panen) Terhadap Perekonomian Dan Kepercayaan Masyarakat Masyarakat Kerinci, Provinsi Jambi," Jurnal Antropologi: $\quad$ Isu-Isu Sosial Budaya 20, no. $1 \quad$ (20 Juni $\quad 2018)$ : 71 , https://doi.org/10.25077/jantro.v20.n1.p71-83.2018.

17 elvin Martius, Esy Maestro, Dan Syeilendra Syeilendra, “Analisis Bentuk Musik Sike Garapan Sanggar Melati Desa Kemantan Kebalai Kabupaten Kerinci," Jurnal Sendratasik 2, no. 1 (1 September 2013): 1-12-12. 
when welcoming guests of honor and tourism. ${ }^{18}$ In addition there are still Balemang culture, Rentak Kudo, Kerinci Regional Stories, folk songs, Tauh, Ngihit Pamun, and etc.

\section{Language}

The Kerinci area has many villages inhabited by various tribes. Indigenous People are the most dominant in this area. Language that is hereditary and characterizes Kerinci is a language called Aksara Incung. Aksara Incung is a meaningful Kerinci language such as beheaded or italic. Aksara Incung usually includes events in life that occurred in the past on bark, buffalo horns, cow horns and so on. ${ }^{19}$ In addition to the Aksara Incung, the Minang language and Javanese also exist in the Kerinci area. Because in reality some who inhabit the Kerinci area are Javanese, Chinese and Minang, at first they came to work and trade which later settled and developed to produce offspring for generations.

3. Nature

Located in a mountainous area with beautiful nature, the Kerinci area has a lot of beauty and natural potential. Natural beauty that is owned to deliver many people from various regions to foreign tourists come to visit this area. The beauty of nature such as Mount Kerinci, Lake Kerinci, Waterfalls, Warm Water, Mount Kahyangan, Pine Forest, and so on. In addition to beautiful nature, natural potential is also abundant in the Kerinci area, such as cinnamon, coffee, potatoes, vegetables, tea, and so on.

\section{Urgency of Arabic Learning Based on Local Wisdom}

Nadlir specifically explained the objectives of learning based on local wisdom as follows ${ }^{20}$ :

1. To know and become familiar with the natural, social, and cultural environment.

2. To rovide the ability and skills as well as knowledge about the area that is useful for himself and the community in general.

18 eke Febrianti, Afifah Asriati, Dan Indrayuda Indrayuda, "Keberadaan Tari Asik Niti Naik Mahligai Di Desa Siulak Mukai Kecamatan Siulak Kabupaten Kerinci,” Jurnal Sendratasik 1, no. 2 (1 Maret 2013): 1-7-7.

${ }^{19}$ Husni Mubarat, "Ekspresi Aksara Incung Kerinci Dalam Penciptaan Seni Kriya," Jurnal Seni, Desain Dan Budaya 1, no. 1 (30 Maret 2016), http://ejournal.uigm.ac.id/ index.php/ Besaung/ article/view/44. 
3. To equip attitudes and behaviors that are in line with the values / rules that apply in the region and preserve and develop the noble values of local culture in order to support regional development and national development.

Mannan explained the importance of local wisdom in learning because it is a form of innovation in the development of learning. With a variety of cultures that exist in Indonesia, it is very supportive to develop a device that is integrated with the local wisdom of the local area. ${ }^{21}$ In accordance with Rabiah's explanation that the reactualization of learning at the school level by developing teaching materials based on character values and local wisdom is very possible in order to fortify the younger generation from the negative impacts that can be caused by globalization and technological progress. ${ }^{22}$

\section{Method}

This research is a library research. Researchers used various references and references from books, National and International Journals available to collect data on the Integration of Local Wisdom in the Kerinci Regency in Arabic Language Learning. Data collection technique is to review the books and journals. The data obtained is then processed with data analysis techniques through stages (1) collecting data on local wisdom owned by the Kerinci area through various sources and literature, including the latest findings regarding the integration of local wisdom in a learning, (2) identifying and understanding characteristics of Arabic learning in Maharah Istima, Kalam, Qiroah, and Kitabah, (3) Analyzing and determining the local wisdom items of the Kerinci area that can be used as Arabic learning material.

${ }^{20}$ M. Nadlir, "Urgensi Pembelajaran Berbasis Kearifan Lokal,” Jurnal Pendidikan Agama Islam (Journal of Islamic Education Studies) 2, no. 2 (2014): 299-330, https://doi.org/10.15642/jpai.2014.2.2.299-330.

${ }^{21}$ Muhammad Nur Mannan, "Pengembangan Perangkat Pembelajaran Berbasis Kearifan Lokal Untuk Mengembangkan Karakter Positif Siswa Sd," Jurnal Inovasi Dan Pembelajaran Fisika 2, no. 2 (2 April 2016): 141-146-146. 


\section{Result and Discussion}

\section{Integration of Local Wisdom in Istima Learning}

Istima is an Arabic language skill that plays an important role in one's language process. Before reaching the stage of speaking, someone will go through the stages of listening (istima) first. If the ability of istima is already good, it will have a good effect on other Arabic language skills. But if ability of istima is inadequate, then the ability of kalam (speaking) will be not fluent. Istima learning is Arabic learning that emphasizes mastery of listening aspects of Arabic material using certain methods and media in accordance with the learning objectives to be achieved. Arabic learning material by integrating the local wisdom of the Kerinci region for istima skills can be given in the form of Kerinci folk songs and Kerinci folklore which had previously been translated into Arabic. Example of the song "Gempo Kerinci 1995" is a song from the Kerinci area with the Arabic version of the lyrics as follows:

$$
\begin{aligned}
& \text { أرض كيرينجي ندية أية....سنة خمسة وتسعون يو أية.... } \\
& \text { هزت الزلزال ندية أية...... لا تنسى يو أياة.... } \\
& \text { البكاء ندياة أية .....في منتصف الليل يو أية.... } \\
& \text { لا شخص رافض ندية أياة.... قوة الله يو أياة.... } \\
& \text { إذا دعا ندية أية.... ليست قادرة يو أية.... } \\
& \text { بسبب الزلزال ندية أية..... ذهب كل شيء يو أية.... } \\
& \text { الحياة مثل ندية أية ....جوز واحد يو أية.... } \\
& \text { أين الجسم ندية أيـة.... يريد ركوب يو أية.... } \\
& \text { كن صابرا ندية أية...... بلية يو أية..... } \\
& \text { هذه بلية ندية أياة..... إرادة الله يو أية..... } \\
& \text { ندعو الله ندية أيـة.... نؤمن بالله يو أية.... } \\
& \text { لا بلياة ندية أية...... حتى تتكرر يو أية.... }
\end{aligned}
$$

${ }^{22}$ Sitti Rabiah, "Pengembangan Materi Ajar Bahasa Makassar berbasis Nilai-Nilai Karakter dan Kearifan Lokal di Sekolah Dasar Kota Makassar," 26 November 2018, https://doi.org/10.31227/osf.io/s8uv5. 
The Kerinci folk song is a folk song that describes the state of the community when the natural disaster (earthquake) that struck Kerinci in 1995. This 1995 earthquake was the most devastating earthquake in the Kerinci region, thus saving a lot of history, sadness and novelty that should not be forgotten by the young generation. Through trials and tests, humans learn to become better people in the future. Istima learning based on local wisdom such as the example of the song above can be given by playing it to the students, so that mufradat become familiar to students. Moreover, it can also be done in the form of a quiz by removing a few words. The missing word must be completed by students.

\section{Integration of Local Wisdom in Kalam Learning}

Kalam learning is part of Arabic learning that emphasizes the ability to speak aspects, both monologically speaking and dialogue. The content of material in kalam learning is to adjust to the expected learning objectives of kalam. Among the examples of drama story scripts from the Kerinci area that can be practiced to practice the ability of muhadasah is the story of "Putri Tangguk", a wife who has an arrogant nature.

$$
\text { زوجة : "يا زوجي! قد تعبت من جني الأرز كل يوم. أريد أن اعتن الأطفال وأزور الجيران. }
$$

$$
\text { زوج : "ثم ما هي خطتك، يازوجتي؟؟ }
$$

زوجة : " أريد أن املأ حظائر الأرز السبعة جانب المنزل غدا لتزويد احتياجاتنا شهورا

بعد تناول الفطور، ذهبت الزوجة وزوجها وأطفالها السبعة لجني الأرز وحمله إلى الحظيرة. في الطريق، انزلقت الزوجة فجأة وسقطت بسبب الأمطار الغزيرة في البارحة.

زوجاة : "الطريق صاخب!" "حسنا! الأرز الذي أحصده سوف أبعثر هنا بدلاً من الرمل حتى

لا يصبح زلقًا ابدا" 
بعد جني الكثير من الأزز، تنتشر معظم الأرز الذي يحملونه تقريبًا على الطريق، لذا لم يعد زلقًا ابدا. ولم يحملوا سوى القليل من الأرز ووضعوه في حظيرة. وفقًا لوعدها، لم تحصد الزوجة الأرز في المزرعة التي يبلغ عرضها السـد. الآن ، تملأ أيامها بقطعة قماش. وقد جعله شغلت ايامها وينسى على اتصال بمنزل الجيران والعناية بأطفاله السبعة مرة أخرى. بل نسيت لطهي الأرز. حتى ذات صباح، استيقظ الأطفال السبعة في حالة هياج ، لأنهم لم يتناولوا العشاء. زوج : " أين هو الأرز ؟" يا زوجتي ...! تعالي! زوجة : "ما الخطأ يا زوجي؟" - مأ

زوج : "انظري! حظائر الأرز لدينا فارغـة. أن يكون هناك لص خذ أرزنا " زوجة : "صحيح يا زوجي! في البارحة أخذ اللص أرزنا في القدر وفي العلب ". "ولكن ، لا بأس، يا زوجي! لا يزال لدينا أمل. أليس مزرعتنا مستودع أرز؟ " قامت الزوجة على الفور بسحب يد زوجها ثم ركضت نحو المزرعة. عند وصولها، ما أخابها الزوجة، لأن آمالها قد اختفت.

زوجة: "يا زوجي! التخلي عن آمالنا. انظر إلى مزرعتنا! ناهيك عن بذور الأرز، لا ينبع الأرز. لا يوجد سوى العشب الكثيف تغطية مزرعتنا". يا الله! موقفي وفعلي إلى الأرز واعتقد أنه مثل الرمل وانتشره على الطريق الموحل، هو خطأي حتى تأتي هذه اللعنة لنا؟ " في الليل، كان تحلم بأن يزورها الرجل العجوز بلحية طويلة يرتدي لباس الأبياض. 
رجل عجوز: أعلم أن لديك مزرعة بعرض السد، لكن المحاصل تمكن أن تملأ أسفل بحيرة كيرينجي إلى السماء. لكن أنت شخصة متكبرة. لقد قللت من شأن الأرز من خلال نثره مثل الرمال كطلاء طريق زلق. اعلمي! من بين الأرز الذي انتشرته، هناك غصن من الأرز الأسود. هو مالكنا. إذا فعلت إلينا هكذا، فلن تكون هناك مشكلة. لكن، لأنك فعلت مالكنا هكذا، نحن غاضبون. لن نأتي مرة أخرى ولا ننمو في مزرعتك. سيكون مستقبلك وعائلتك بائسة. رزقك ستكون مثل رزق الدجاجة. نتائج العمل ليوم واحد، وهو يكفي لتناول الطعام في اليوم. لن تتمكن أنت وعائلتك من تناول الطعام إذا لم من قبل. ستكون حياتك حقًا بمثابة دجاجة، تفوح وتناول الطعام ...".

\section{زوجاة: يا الله... اغفرلي، اسف أن أكون متكبرة وتقبرية بتشتيت الأرز لطلاء الطريق الزلق.}

Conversations about the story of "Putri Tangguk" can be practiced in the form of drama in class. In learning activities through the integration of local wisdom into Arabic learning, the students also know the Kerinci regional story. Then students must be able to take lessons and moral messages from muhadasah that are practiced. The lessons that can be got from the story of "Putri Tangguk" are we have to appreciate everything we have today. Do not waste it, because later we will regret later will be useless.

In kalam learning, for local wisdom content can also be used by using the location plan media known by students. The kalam exercise here is to ask students to explain the travel route that must be taken based on the following location plan: 


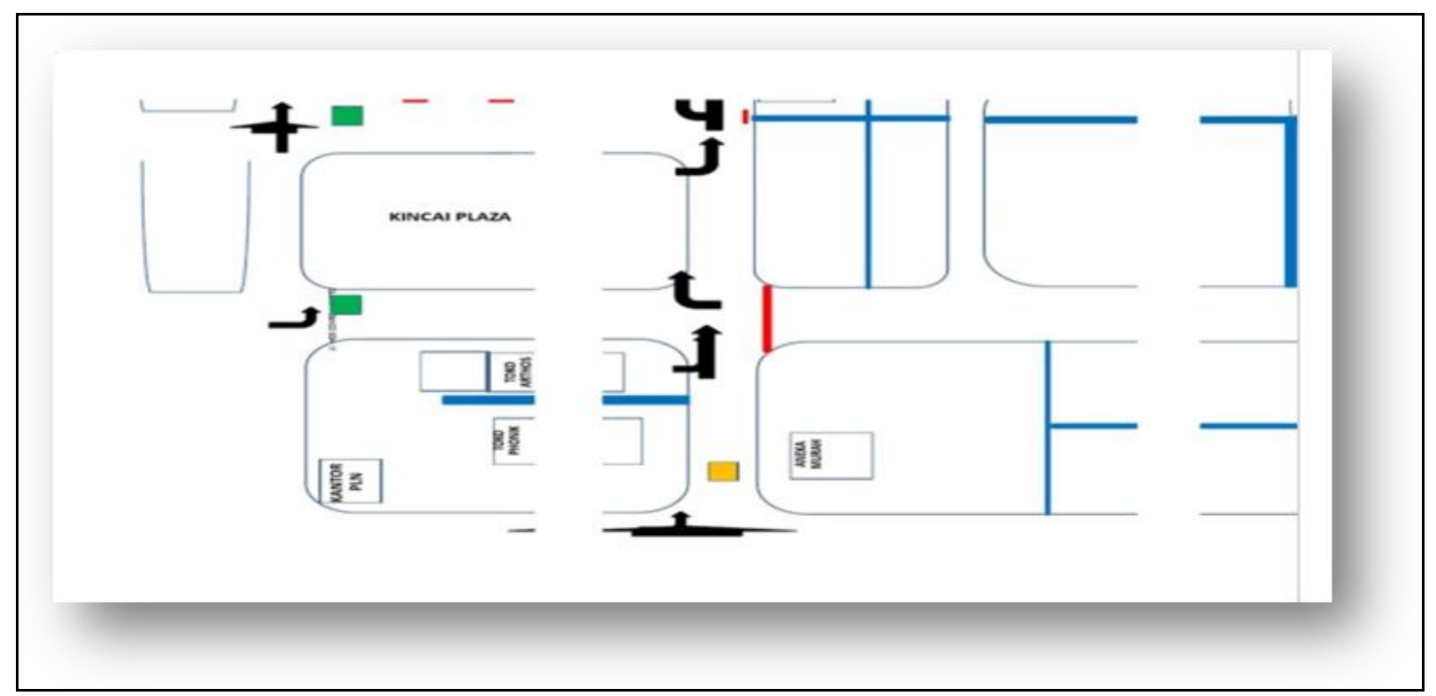

Figure 1. The Location Map of Merdeka Hall in Kerinci Regency

Based on the location map, the teacher can ask a number of questions, such as:

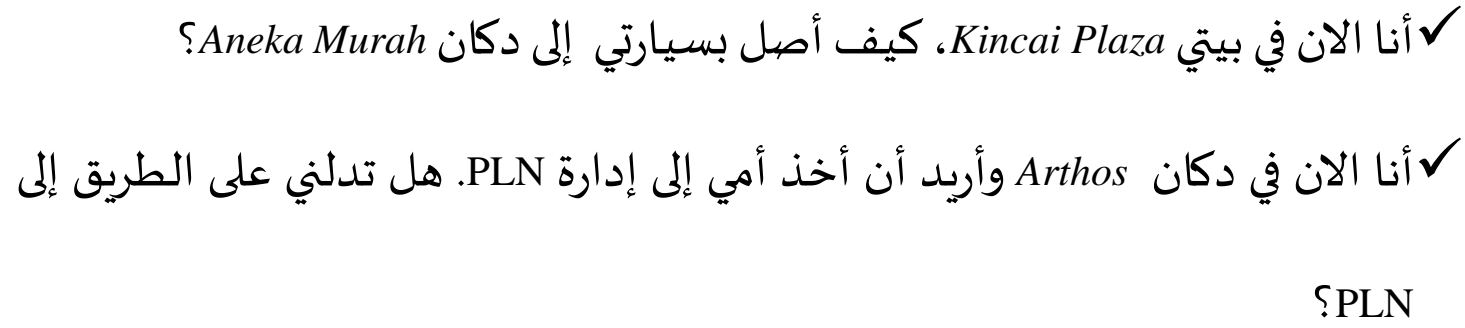

Students are required to be able to understand the location map in order to be able to answer every question posed. By understanding the location map, not only is the new vocabulary that they obtained but also knowledge about the area in Kerinci Regency.

\section{Integration of Local Wisdom in Qiroah Learning}

Qiroah learning is Arabic learning that emphasizes aspects of students' reading ability. Reading is not only done by making loud and loud voices, but can also be done silently or silent reading. Reading is basically a process of translating written symbols into meaning, and not merely changing written symbols into sound symbols. In essence, reading is a mental process for obtaining information contained in written material. ${ }^{23}$

Integration of the local wisdom of the Kerinci region in Arabic learning can be done by providing reading texts (nash) containing local wisdom of the Kerinci area, such as culture, customs, tourism, and so forth. Here the author gives an example of Arabic qiroah text material entitled "Danau Kerinci" or "Lake Kerinci". 


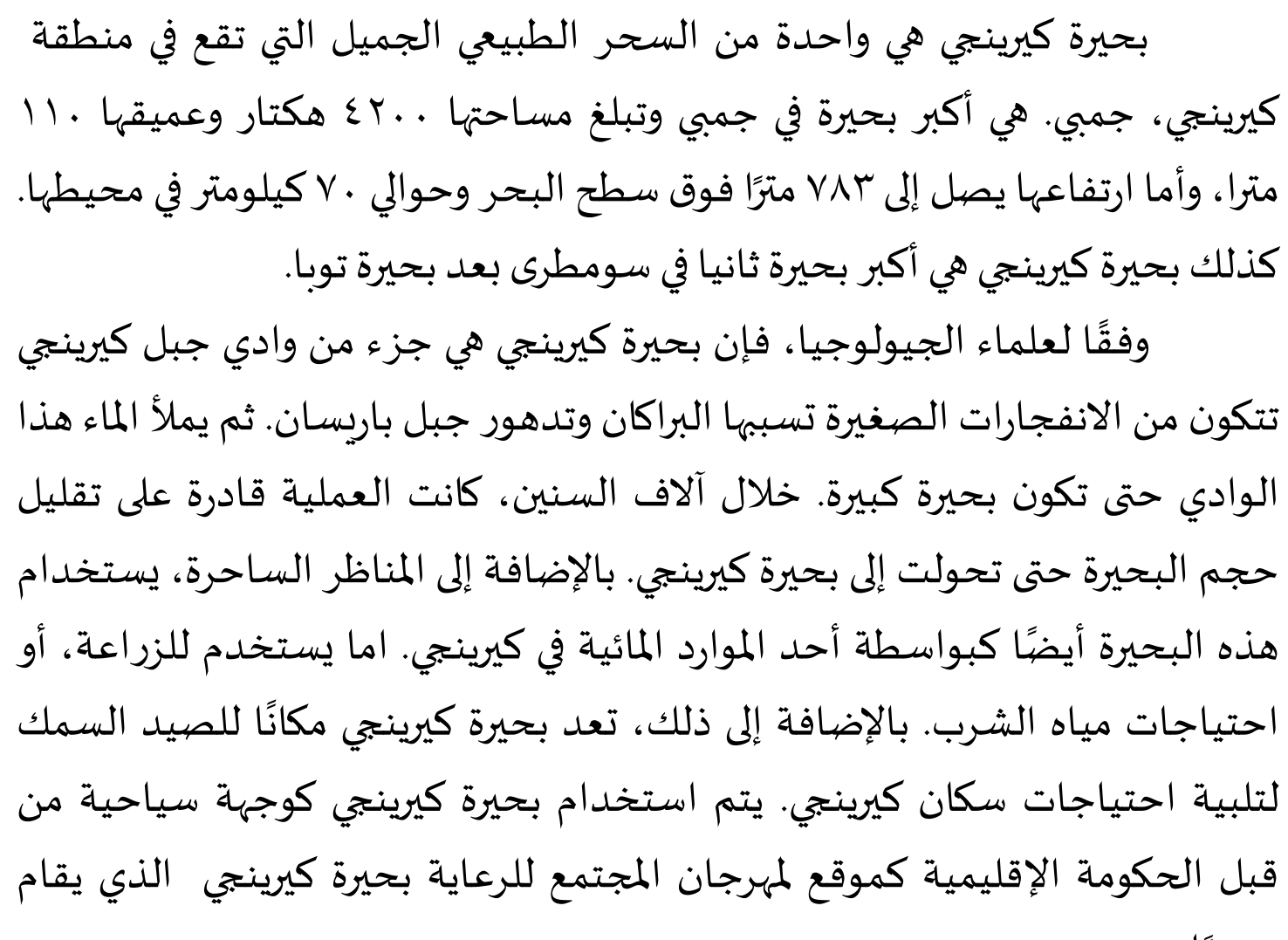

With the material containing local wisdom, entitled "Danau Kerinci", can help students in recognizing the nature of Kerinci, the type of tourism in the Kerinci region, in addition to mastering the vocabulary relating to natural attractions. Arabic learning with the reading material "Danau Kerinci", can be given by asking students to read the text, either silently or aloud. Then ask them to look for new mufradat meanings that are not yet known in the dictionary, so that they are able to understand the text as a whole. To find out their mastery of the text, can be asked or ask them to explain what is obtained after reading the text. If students are able to understand the text well, then this shows the purpose of learning qiroah by integrating the local wisdom of the Kerinci area can be achieved properly. Besides mastering the vocabulary understanding of one of the wisdom of the Kerinci area can also be achieved. Parmini revealed that learning material in the form of folklore needs to be preserved and developed in order to improve the emotional intelligence of the nation, especially students as the nation's next generation. Teaching

${ }^{23}$ Imam Asrori dan Moh. Ahsanuddin, Media Pembelajaran Bahasa Arab dari Kartu Sederhana Sampai Web Penjelajah Dunia (Malang: CV. Bintang Sejahtera, 2016). 
folklore is not only useful for continuing moral values but also preserving the story as a national cultural heritage. ${ }^{24}$

\section{Integration of Local Wisdom in Kitabah Learning}

Writing is an activity of delivering messages using written language as the medium. Message is the content or content contained in an article, while writing is a symbol of language that can be seen and agreed upon by the user. In written communication, there are at least four elements involved, namely the writer as the messenger, the content of the writing, the channel or media in the form of writing, and the reader as the recipient of the message.

Kitabah Learning in Arabic Learning is a learning process that emphasizes mastery of the aspects of writing through strategies, media, and materials that are appropriate to the intended writing goals. With this writing activity in Arabic learning, it is able to practice the ability of qawaid and mastery of the mufradat. Mufradat in question is adapted to the theme and content of the material presented by the teacher.

Writing skills have two aspects, namely the ability to form letters and mastering each spelling. The essence of writing skills is in the second aspect. The reality that is seen is that many people can write Arabic very well, but do not understand the meaning they write, let alone give birth to their own intentions and thoughts in Arabic. ${ }^{25}$

Writing activities have stages in accordance with the development of students. Starting from the most basic stages, namely copying letters, copying words, copying sentences, copying paragraphs and so on. Copying is not only at the level of moving the writing in the textbook to the student's notebook in exactly the same form, but copying can also be done by writing Arabic or calligraphy. Moving on from copying, the next step in learning to write is writing. Composing is done with a specific theme or with a free theme.

Material containing local wisdom is one form of material that can be integrated in learning Kitabah proficiency in Arabic, namely by including themes written with local wisdom, such as instructing students to write cultural activities carried out around their respective environments such as traditional ceremonies in Kenduri Sko, balemang, experience following the Niti Naik Mahligai Dance, Tauh, Sike Rebana, Asyek Nyabung,

\footnotetext{
${ }^{24}$ Ni Putu Parmini, "Eksistensi Cerita Rakyat Dalam Pendidikan Karakter Siswa SD Di Ubud," Jurnal Kajian Bali (Journal of Bali Studies) $5, \quad$ no. 2 (2015), https://ojs.unud.ac.id/index.php/kajianbali/article/view/16784.

${ }^{25}$ Ahmad Fuad Effendy, Metodologi Pengajaran Bahasa Arab (Malang: Misykat, 2012).
} 
Rangguk, Ngihit Pamun, writing about recreational experiences and holiday tours in Kerinci that they have gone through, writing Kerinci folklore, Kerinci folk songs and so forth. Muhammad Priyatna expressed his support for local wisdom found in several indigenous groups / communities in Indonesia that contain many of the nation's noble cultural values that are still strong into the character's identity of the citizens. ${ }^{26}$

\section{Conclusion}

It can be concluded that integrating the local wisdom of the Kerinci area into Arabic learning can be done by modifying the content of the subject matter, which is to include the forms of local wisdom possessed by the Kerinci region in learning istima, kalam, qiroah, and kitabah. This is done so that the knowledge gained by students is not only in mastering Arabic vocabulary and qawaid, but also about the natural environment such as, Kerinci folk songs, Kerinci folklore, Kerinci tourism, and so forth. Implicitly, it can be explained that the integration of local wisdom in Arabic learning can foster a sense of belonging to the region and nationalism will be formed in the younger generation who learn the Arabic. The results of this study will open space for the next researcher to look deeper into the integration of local wisdom in Arabic learning through the direct implementation of this material containing local wisdom in Arabic learning until its level of effectiveness is known, in order to strengthen the existence of Arabic in the world of education and foster the love of participants educate local wisdom. In addition, there is a need for other integration of Arabic learning, and finally it will enrich Arabic itself.

\section{Acknowledgment}

We are grateful to Arabic Education Study Program of Institut Agama Islam Negeri Curup for the support so this research can be completed on time.

\section{References}

Aljojo, Nahla, Iqbal Alsaleh, dan Areej Alshamasi. "Difficulties in adapting feedback for individual learning styles in the Arabic Teacher Assisting and Subject Adaptive Material (TASAM) system." International Journal of Management in Education

${ }^{26}$ Muhammad Priyatna, "Pendidikan Karakter Berbasis Kearifan Lokal," Edukasi Islami: Jurnal Pendidikan Islam 5, no. 10 (25 Oktober 2017), https://doi.org/10.30868/ei.v5i10.6. 
10, no. 3 (1 Januari 2016): https://doi.org/10.1504/IJMIE.2016.077510.

Alkazemi, Basem, Mohammed Nour, Atif Naseer, Ammar Natto, dan Grami Grami. "AccurIT: a prototype of a machine translation engine for English to Arabic translation." International Journal of Innovation and Learning 26, no. 2 (1 Januari 2019): 115-30. https://doi.org/10.1504/IJIL.2019.101274.

Amin, Tamer, dan Diala Badreddine. "Teaching science in Arabic: diglossia and discourse patterns in the elementary classroom." International Journal of Science Education $0, \quad$ no. $\quad 0 \quad$ (28 Juni 2019$)$ : $1-41$. https://doi.org/10.1080/09500693.2019.1629039.

Asrori, Imam, dan Moh. Ahsanuddin. Media Pembelajaran Bahasa Arab dari Kartu Sederhana Sampai Web Penjelajah Dunia. Malang: CV. Bintang Sejahtera, 2016.

Desfandi, Mirza. "urgensi kurikulum pendidikan kebencanaan berbasis kearifan lokal di indonesia." Sosio-didaktika: Social Science Education Journal 1, no. 2 (28 Desember 2014): 191-198 -198. https://doi.org/10.15408/sd.v1i2.1261.

Effendy, Ahmad Fuad. Metodologi Pengajaran Bahasa Arab. Malang: Misykat, 2012.

Erzad, Azizah Maulina, dan Suciati Suciati. "The Existence of Kudus Islamic Local Culture to Prevent Radicalism in Globalization Era." QIJIS (Qudus International Journal of Islamic Studies) 6, no. 1 (4 Juli 2018): 39. https://doi.org/10.21043/qijis.v1i1.3460.

Febrianti, Eke, Afifah Asriati, dan Indrayuda Indrayuda. "Keberadaan Tari Asik Niti Naik Mahligai Di Desa Siulak Mukai Kecamatan Siulak Kabupaten Kerinci." Jurnal Sendratasik 1, no. 2 (1 Maret 2013): 1-7-7.

Gularso, Dhiniaty, Sugito Sugito, dan Zamroni Zamroni. "Kawruh Pamomong: Children Education Based on Local Wisdom in Yogyakarta." Jurnal Cakrawala Pendidikan 38, no. 2 (29 Juni 2019): 343-55. https://doi.org/10.21831/cp.v38i2.21556.

Khusniati, Miranita. "Model Pembelajaran Sains Berbasis Kearifan Lokal Dalam Menumbuhkan Karakter Konservasi." Indonesian Journal of Conservation 3, no. 1 (1 Juni 2014). https:// journal.unnes.ac.id/nju/ index.php /ijc/article/ view/3091.

Leksono, Suroso Mukti, dan Nuryani Rustaman. "Pengaruh Penerapan Program Perkuliahan Biologi Konservasi Berbasis Kearifan Lokal Terhadap Kemampuan Literasi Biodiversitas Mahasiswa Calon Guru Biologi," no. 1 (2015): 8.

Mannan, Muhammad Nur. "pengembangan perangkat pembelajaran berbasis kearifan lokal untuk mengembangkan karakter positif siswa sd." Jurnal inovasi dan pembelajaran fisika 2, no. 2 (2 April 2016): 141-146-146.

Martius, Elvin, Esy Maestro, dan Syeilendra Syeilendra. “Analisis Bentuk Musik Sike Garapan Sanggar Melati Desa Kemantan Kebalai Kabupaten Kerinci.” Jurnal Sendratasik 2, no. 1 (1 September 2013): 1-12-12. 
Mubarat, Husni. "Ekspresi Aksara Incung Kerinci Dalam Penciptaan Seni Kriya." Jurnal Seni, Desain Dan Budaya 1, no. 1 (30 Maret 2016). http://ejournal.uigm.ac.id/index.php/Besaung/article/view/44.

Mulyana, Agus. "Mengembangkan Kearifan Lokal Dalam Pembelajaran Sejarah,” 2015, 10.

Nadlir, M. "Urgensi Pembelajaran Berbasis Kearifan Lokal." Jurnal Pendidikan Agama Islam (Journal of Islamic Education Studies) 2, no. 2 (2014): 299-330. https://doi.org/10.15642/jpai.2014.2.2.299-330.

Oktafia, Renny, dan Imron Mawardi. "IslamIc Values In The TradITIon of SamIn CommunITy In EasT JaVa." QIJIS (Qudus International Journal of Islamic Studies) 5, no. 1 (2017): 18.

Parmini, Ni Putu. "Eksistensi Cerita Rakyat Dalam Pendidikan Karakter Siswa SD Di Ubud." Jurnal Kajian Bali (Journal of Bali Studies) 5, no. 2 (2015). https://ojs.unud.ac.id/index.php/kajianbali/article/view/16784.

Priyatna, Muhammad. "Pendidikan Karakter Berbasis Kearifan Lokal." Edukasi Islami: Jurnal Pendidikan Islam 5, no. $10 \quad$ (25 Oktober 2017). https://doi.org/10.30868/ei.v5i10.6.

Rabiah, Sitti. "Pengembangan Materi Ajar Bahasa Makassar berbasis Nilai-Nilai Karakter dan Kearifan Lokal di Sekolah Dasar Kota Makassar," 26 November 2018. https://doi.org/10.31227/osf.io/s8uv5.

Ramadani, Yolla, dan Astrid Qommaneeci. "Pengaruh Pelaksanaan Kenduri Sko (Pesta Panen) Terhadap Perekonomian Dan Kepercayaan Masyarakat Masyarakat Kerinci, Provinsi Jambi.” Jurnal Antropologi: Isu-Isu Sosial Budaya 20, no. 1 (20 Juni 2018): 71. https://doi.org/10.25077/jantro.v20.n1.p71-83.2018.

Rosala, Dedi. "Pembelajaran Seni Budaya Berbasis Kearifan Lokal dalam Upaya Membangun Pendidikan Karakter Siswa di Sekolah Dasar." Ritme 2 (Februari 2016).

Sa-ngiamwibool, Amporn. "Raising learner awareness of local wisdom in tour-related project teaching." Indonesian Journal of Applied Linguistics 1, no. 2 (5 Januari 2012): 1. https://doi.org/10.17509/ijal.v1i2.659.

Selim, Nadia. "Arabic teaching at Islamic Schools: A C.A.L.L for resource development." 1 Februari 2016.

Setiadi, Syamsi. "Peningkatan Keterampilan Kitabah Arabiyah Mahasiswa Melalui Metode Tutor Sebaya." Jurnal Al Bayan: Jurnal Jurusan Pendidikan Bahasa Arab 9, no. 1 (21 Juli 2017): 31-39. https://doi.org/10.24042/albayan.v9i1.1094.

Sumardjoko, Bambang. "Model Of Civic Education Learning Based On The Local Wisdom For Revitalizing Values Of Pancasila." Jurnal Cakrawala Pendidikan 37, no. 2 (29 Juni 2018). https://doi.org/10.21831/cp.v37i2.18037. 
Sumarmi, dan Amiruddin. Pengelolaan Lingkungan Berbasis Kearifan Lokal. Yogyakarta: Aditya Medai Publishing, 2014.

Utari, Unga, I. Nyoman Sudana Degeng, dan Sadun Akbar. "Pembelajaran Tematik Berbasis Kearifan Lokal Di Sekolah Dasar Dalam Menghadapi Masyarakat Ekonomi Asean (MEA)." Jurnal Teori Dan Praksis Pembelajaran IPS 1, no. 1 (30 April 2016): 39—44. https://doi.org/10.17977/jtp2ips.v1i1.5861.

Wulandari, Wahyu Trias, dan Mundilarto Mundilarto. "Developing Physics Active Learning Kits for Local Wisdom-Based Learning Tournament." Cakrawala Pendidikan, no. 3 (2016): 13. 